\title{
ANALISA TOTAL BAKTERI, KADAR AIR DAN pH PADA RUMPUT LAUT (Kappaphycus alvarezii) DENGAN DUA METODE PENGERINGAN
}

\author{
Evan Ch. Kumesan ${ }^{1}$, Engel V. Pandey ${ }^{2}$ dan Helen J. Lohoo ${ }^{2}$ \\ ${ }^{1)}$ Mahasiswa pada Program Studi Teknologi Hasil Perikanan FPIK Unsrat Manado \\ ${ }^{2)}$ Staf pengajar pada Program Studi Teknologi Hasil Perikanan FPIK Unsrat Manado \\ Email: kumesan98@gmail.com
}

\begin{abstract}
Rumput laut sebagai salah satu komoditas ekspor merupakan sumber devisa bagi Negara dan budidayanya merupakan sumber pendapatan nelayan, dapat menyerap tenaga kerja, serta mampu memanfaatkan lahan perairan pantai di kepulauan Indonesia yang sangat potensial. Tujuan dari penelitian ini adalah menghitung jumlah koloni bakteri, dan menentukan jumlah kadar air dan $\mathrm{pH}$ pada rumput laut (Kappaphycus alvarezii) dengan dua metode pengeringan. Penelitian ini menerapkan metode deskriptif yaitu metode analisa yang memberikan gambaran secermat mungkin tentang suatu individu, keadaan gejala atau kelompok tertentu. Hasil penelitian ini menunjukkan bahwa jumlah koloni bakteri yang tumbuh pada rumput laut rata-rata menunjukkan hasil yang tidak jauh berbeda, rumput laut yang dikeringkan dengan menggunakan sinar matahari dari pukul $08.00-12.00$ selama 40 jam adalah $5,45 \times 10^{5}$ CFU/gr, dan untuk pukul 12.00-16.00 selama $40 \mathrm{jam} 5,13 \times 10^{5} \mathrm{CFU} / \mathrm{gr}$. Sedangkan, untuk pengeringan menggunakan cabinet dryer selama 12 jam adalah 5,39 $\times 10^{5} \mathrm{CFU} / \mathrm{gr}$ dan pengeringan selama 24 jam adalah $5,48 \times 10^{5} \mathrm{CFU} / \mathrm{gr}$. Untuk kadar air nilai tertinggi yaitu $17,25 \%$ pada pengeringan menggunakan cabinet dryer selama $12 \mathrm{jam}$. Dan nilai rata-rata terendah yaitu $10,75 \%$ pada pengeringan sinar matahari selama 40 jam. Dan untuk nilai $\mathrm{pH}$, nilai tertinggi yaitu 5,58 pada pengeringan menggunakan sinar matahari pada pukul 08.00-12.00 selama 40 jam dan untuk nilai terendah yaitu 4,93 pada pengeringan menggunakan cabinet dryer selama 24 jam.
\end{abstract}

Kata Kunci: cabinet dryer, TPC, Kapphaphycus alvarezii.

\section{PENDAHULUAN}

Luas wilayah Indonesia sebagian besar, yaitu dua pertiganya merupakan wilayah perairan. United Nation Convention on the Law of the Sea (UNCLOS) pada tahun 1982 melaporkan bahwa luas perairan Indonesia adalah 5,8 juta $\mathrm{km}^{2}$ dan didalamnya terdapat $27,2 \%$ dari seluruh spesies flora dan fauna di dunia. Rumput laut atau lebih dikenal dengan sebutan seaweed merupakan salah satu sumberdaya hayati yang sangat melimpah di perairan Indonesia, yaitu sekitar 8,6\% dari total biota di laut (Dahuri, 1998).

Rumput laut dapat menghasilkan devisa serta pendapatan masyarakat terutama masyarakat pesisir. Karena rumput laut yang utamanya dari kelas rhodophyceae (ganggang merah) selain mengandung karaginan dan agaragar juga mempunyai kandungan gizi yang penting yaitu yodium. Salah satu jenis rumput laut merah yang bernilai ekonomis penting yaitu rumput laut Kappaphycus alvarezii adalah rumput laut penghasil karaginan (carragenophyte). Jenis karaginan yang dihasilkan dari rumput laut ini adalah kappa karagenan (Winarno, 2008).

Kappaphycus alvarezii termasuk dalam rumput laut yang mempunyai nilai komersial dan komoditas ekspor. Rumput laut jenis ini merupakan salah satu carragenophytes yaitu rumput laut penghasil karaginan. Hasil olahan Kappaphycus alvarezii banyak digunakan sebagai pengemulsi, pembentuk gel, penstabil, dan pengental (Hudaya, 2008).

Provinsi Sulawesi Utara menyimpan potensi pengembangan budidaya rumput laut, salah satunya jenis Kappaphycus alvarezii. Rumput laut penghasil kappa karaginan ini telah dibudidayakan pada beberapa lokasi, salah satunya di daerah perairan Desa Arakan Kecamatan Tatapaan, Kabupaten Minahasa Selatan. Potensi budidaya di perairan Arakan \pm $1.500 \mathrm{Ha}$, dan telah termanfaatkan untuk budidaya rumput laut $450 \mathrm{Ha}$. Produksi rumput laut dari desa Arakan pada tahun 1992-2000 mencapai 150-2000 ton kering per bulan, namun pada tahun 2006-2012 produksi rumput laut mengalami penurunan yaitu $1-5$ ton kering per bulan (Teurupun 2013). 
Pengeringan merupakan tahapan pengolahan yang cukup penting karena terkait dengan kadar air bahan sebagai faktor yang berpengaruh terhadap penampakkan, tekstur, cita rasa, nilai gizi bahan pangan, dan terutama aktivitas mikroorganisme (Bintang 2013). Pengeringan pada rumput laut adalah proses utama dari pengolahan rumput laut itu sendiri sebagai bahan baku industri seperti karagenan. Oleh karena itu berhubungan dengan pengeringan sehingga diperlukan untuk menganalisa kadar air, $\mathrm{pH}$ dan analisa total bakteri dari rumput laut tersebut untuk mengetahui apakah sudah memenuhi standar mutu yang telah ditetapkan.

Metode pengeringan ini dilakukan dengan dua perlakuan yaitu pengeringan dengan sinar matahari dan pengeringan dengan alat pengering buatan atau cabinet dryer. Dimana pengeringan di bawah sinar matahari dengan lama pengeringan selama 40 jam atau 4 jam setiap hari selama 10 hari dimulai pada pukul 08.00-12.00 dan 12.00-16.00, sedangkan untuk cabinet dryer dengan sumber panas dari kompor dengan lama pengeringan selama 12 jam dan 24 jam pada suhu $60^{\circ} \mathrm{C}$ dan sampel digantung pada pengait yang ada di dalam cabinet dryer.

\section{METODOLOGI PENELITIAN}

Penelitian ini menerapkan metode deskriptif yaitu metode analisa yang memberikan gambaran secermat mungkin tentang suatu individu, keadaan gejala atau kelompok tertentu.

\section{Hipotesis Penelitian}

Hipotesis merupakan jawaban sementara dari rumusan masalah penelitian (Sugiono, 2008). Berdasarkan masalah yang diajukan dan teori yang diuraikan maka dapat dirumuskan hipotesis yaitu:

1. Ada pengaruh terhadap jumlah koloni bakteri, kadar air dan $\mathrm{pH}$ pada rumput laut (Kappaphycus alvarezii) yang dikeringkan dengan dua metode pengeringan.

2. Tidak Ada pengaruh terhadap jumlah koloni bakteri, kadar air dan $\mathrm{pH}$ pada rumput laut yang dikeringkan dengan dua metode pengeringan.

\section{Tempat dan Waktu Penelitian}

Penelitian ini dilaksanakan di Laboratorium Teknologi Penanganan dan Pengolahan Hasil Perikanan dan Pengendalian
Mutu Hasil Perikanan selama bulan SeptemberOktober 2016.

\section{Bahan dan Alat}

Alat yang digunakan ialah: cabinet dryer, Erlenmeyer 1000ml, Erlenmeyer 250ml, Pipet $1 \mathrm{ml}$, gelas ukur, magnetic stirer, cawan petri, autoclave, Inkubator, tabung hush, spatula, oven, timbangan analitik, cawan porselen, desikator, $\mathrm{pH}$ meter, gelas beker $100 \mathrm{ml}$.

Bahan yang digunakan yaitu sampel rumput laut kering Kappaphyus alvarezii, Nutrient Agar, akuades, $\mathrm{NaCl} 0,9 \%$, larutan buffer, alkohol $70 \%$, alumunium foil, wrapping crap, tissue, masker, handskun, spritus.

\section{Tata Laksana Penelitian}

Rumput laut diambil dari desa Arakan, Kabupaten Minahasa Selatan melalui petani budidaya rumput laut. Kemudian di bawa ke Laboratorium Teknologi Penanganan dan Pengolahan Hasil Perikanan Unsrat untuk dikeringkan. Pengeringan rumput laut menggunakan dua cara yaitu Pengeringan menggunakan cabinet dryer dan sinar matahari dan setelah dikeringkan sampel dibawa ke Laboratorium Pengendalian Mutu Hasil Perikanan untuk dianalisa TPC, Kadar Air dan $\mathrm{pH}$.

\section{Parameter yang Digunakan \\ Analisa Total Bakteri (Total Plate Count)}

Prosedur perhitungan jumlah bakteri menurut modifikasi Fardiaz (1993) ialah sebagai berikut:

1. Semua peralatan disterilkan dengan menggunakan autoclave pada tekanan 15psi selama 15 menit pada suhu $121^{\circ} \mathrm{C}$.

2. Ditimbang NA (Nutrient Agar) dan masukkan ke dalam Erlenmeyer dan diberi Akuades sebanyak $250 \mathrm{ml}$ setelah itu homogenkan dengan magnet putar (Magnetic Stirer) pH diatur pada 7,0 selanjutnya direbus sampai larut dan disterilkan dengan autoclave pada tekanan 15 psi dengan suhu $121^{\circ} \mathrm{C}$ selama 15 menit.

3. Disiapkan larutan pengencer $0,9 \% \mathrm{NaCl}$, masing-masing pengenceran tingkat pertama $90 \mathrm{ml}$ dan mulut Erlenmeyer ditutupi alumunium foil, sedangkan untuk tingkat pengenceran kedua dan ketiga masing-masing diambil $9 \mathrm{ml} \mathrm{NaCl} \quad 0,9 \%$ kemudian dimasukkan ke dalam tabung 
hush yang dilengkapi dengan penutup. Semua larutan pengenceran disterilkan dengan autoclave dengan suhu $121^{\circ} \mathrm{C}$ tekanan 15 psi selama 15 menit.

4. Sampel diblender dan ditimbang 10 gram secara aseptis kemudian dimasukkan ke dalam $90 \mathrm{ml} \mathrm{NaCl} \quad 0,9 \%$ steril sehingga diperoleh larutan dengan tingkat pengenceran $10^{-1}$. Dari pengenceran $10^{-1}$ dipipet $1 \mathrm{ml}$ ke dalam tabung reaksi 2, kemudian homogenkan sehingga diperoleh pengenceran $10^{-2}$, lanjutkan sampai diperoleh pengenceran $10^{-4}$.

5. Dari setiap pengenceran diambil $1 \mathrm{ml}$ pindahkan ke cawan etri steril yang telah diberi kode untuk tiap sampel pada tingkat pengenceran tertentu.

6. Ke dalam semua cawan petri dituangkan secara aseptis NA sebanyak 15-20ml. setelah penuangan, cawan petri digoyang perlahan-lahan sambil diputar 3 kali ke kiri, ke kanan, lalu ke depan, ke belakang, kiri dan kanan, kemudian didinginkan sampai agar mengeras. Setelah NA padat dimasukkan ke dalam incubator selama 24 jam pada suhu $37^{\circ} \mathrm{C}$ dengan posisi terbalik. Setelah masa inkubasi berakhir, dilakukan perhitungan jumlah bakteri dan jumlah bakteri dikalikan dengan 1 per pengenceran. Perhitungan jumlah koloni menggunakan rumus sebagai berikut :

Total Bakteri $=$ Jumlah Koloni Bakteri $\mathrm{x}$ 1/Pengenceran.

\section{Analisa Kadar Air (AOAC, 1995)}

Analisis kadar air dengan menggunakan oven. Kadar air dihitung sebagai persen berat, artinya berapa gram berat contoh dengan yang selisih berat dari contoh yang belum diuapkan dengan contoh yang telah (dikeringkan). Jadi kadar air dapat diperoleh dengan menghitung kehilangan berat contoh yang dipanaskan. Urutan kerjanya sebagai berikut:

1. Cawan porselen disterilkan dalam Oven selama 1 jam dengan suhu $105^{\circ} \mathrm{C}$. kemudian didinginkan selama 15 menit dan ditimbang beratnya (A gram).

2. Sampel ditimbang sebanyak 2 gram dan ditaruh dalam cawan porselen yang telah diketahui beratnya (B gram). Sampel dalam porselen ini kemudian dikeringkan dalam oven pada suhu $105^{\circ} \mathrm{C}$ sampel konstan selama 3 jam, selanjutnya didinginkan dalam desikator selama 15 menit dan ditimbang (C gram)

3. Penimbangan ini diulang sampai diperoleh berat yang konstan.

$$
\text { Kadar Air }=\frac{(B-C)}{(B-A)} \times 100
$$

Dimana :

$$
\begin{aligned}
\mathrm{A}= & \text { Berat kering cawan (gr) } \\
\mathrm{B}= & \text { Berat kering cawan dan sampel awal (gr) } \\
\mathrm{C}= & \text { Berat kering cawan dan sampel setelah } \\
& \text { dikeringkan (gr) }
\end{aligned}
$$

Analisa Penentuan Nilai pH (AOAC, 1995)

Bahwa penentuan $\mathrm{pH}$ dapat dilakukan dengan menggunakan $\mathrm{pH}$ meter, dengan urutan kerja sebagai berikut :

1. Timbang sampel yang telah dirajang kecilkecil sebanyak 10 gr dan di homogenkan menggunakan mortar dengan $20 \mathrm{ml}$ Aquades selama 1 menit.

2. Tuangkan ke dalam beker gelas $10 \mathrm{ml}$, kemudian diukur pHnya dengan menggunakan $\mathrm{pH}$ meter.

3. Sebelum $\mathrm{pH}$ meter digunakan, harus ditera kepekaan jarum penunjuk dengan larutan buffer $\mathrm{pH} 7$.

4. Besarnya $\mathrm{pH}$ adalah pembacaan jarum penunjuk $\mathrm{pH}$ setelah jarum skala konstan kedudukannya.

\section{HASIL DAN PEMBAHASAN}

\section{Hasil Total Koloni Bakteri}

Hasil perhitungan koloni bakteri pada rumput yang dikeringkan dengan dua metode pengeringan yaitu menggunakan sinar matahari dan cabinet dryer dengan menggunakan suhu inkubasi $37^{\circ} \mathrm{C}$ dapat dilihat pada gambar 1 .

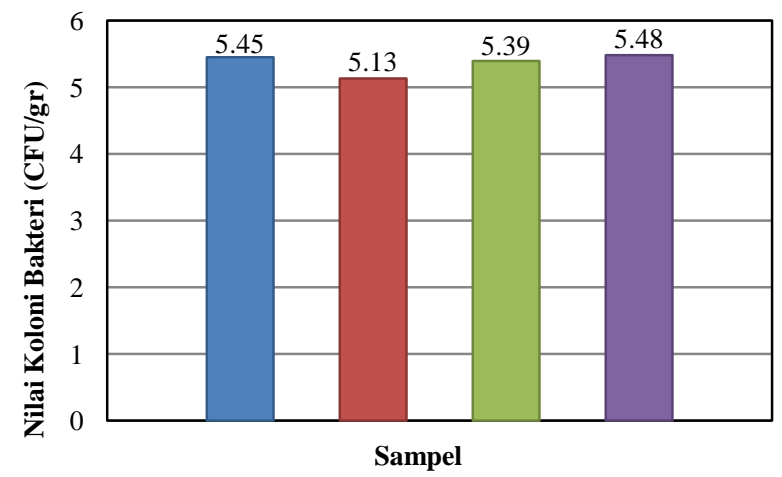

Gambar 1. Histogram nilai koloni bakteri (CFU/gr) rumput laut (Kappapphycus alvarezii) kering dengan dua metode pengeringan.

Gambar 3 menunjukan bahwa jumlah koloni bakteri yang tumbuh pada rumput laut kering rata-rata menunjukan hasil yang tidak 
jauh berbeda, rumput laut yang dikeringkan menggunakan sinar matahari selama 40 jam pada pukul $08.00-12.00$ adalah $5,45 \times 10^{5}$ CFU/gr, dan untukpengeringan 40 jam pada

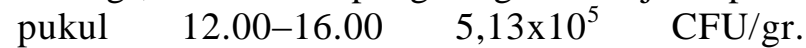
Sedangkan, untuk pengeringan menggunakan cabinet dryer untuk pengeringan selama 12 jam adalah $5,39 \times 10^{5} \mathrm{CFU} / \mathrm{gr}$ dan pengeringan selama 24 jam adalah $5,48 \times 10^{5} \quad$ CFU/gr. Berdasarkan data di atas bahwa untuk nilai koloni bakteri tertinggi yaitu $5,48 \times 10^{5} \mathrm{CFU} / \mathrm{gr}$ dengan pengeringan menggunakan cabinet dryer selama 24 jam, dan untuk nilai terendah koloni bakteri yaitu $5,13 \times 10^{5} \mathrm{CFU} / \mathrm{gr}$ pada pengeringan sinar matahari dari pukul 12.00 16.00 .

Menurut penelitian Suptijah (2003), menyatakan bahwa rumput laut memiliki kandungan kimia karagenan dan senyawa fenol, terutama flavanoid, selanjutnya Pelczar et al. (1977) dalam Prajitno (2007), menyatakan bahwa persenyawaan flavanoid sebagai antibakteri menghambat pertumbuhan dan metabolisme bakteri dengan cara merusak membran sitoplasma dan mendenaturasi protein sel. Volk dan Wheeler (1988) menambahkan, senyawa flavonoid dapat merusak membran sitoplasma yang dapat menyebabkan bocornya metabolit penting dan menginaktifkan sistem enzim bakteri. Kerusakan ini memungkinkan nukleotida dan asam amino merembes keluar dan mencegah masuknya bahan-bahan aktif ke dalam sel, keadaan ini dapat menyebabkan kematian bakteri. Berdasarkan hasil penelitian tersebut dapat dilihat bahwa pertumbuhan bakteri pada rumput laut kering terhambat karena adanya senyawa flavonoid yang terkandung dalam rumput laut sebagai antibakteri.

\section{Hasil Analisa Kadar Air}

Hasil analisa kadar air pada rumput laut kering yang dikeringkan dengan sinar matahari dan cabinet dryer dapat dilihat pada Gambar 2.

Berdasarkan Gambar 2, menunjukan bahwa pengeringan yang berbeda dengan menggunakan sinar matahari dan cabinet dryer, nilai rata-rata untuk kadar air dari rumput laut kering dengan perlakuan sinar matahari selama 40 jam pada pukul 08.00-12.00 yaitu $13,75 \%$ dan pengeringan dengan sinar matahari selama 40 jam pada pukul $12.00-16.00$ yaitu $10,75 \%$. Sedangkan pengeringan menggunakan cabinet dryer selama 12 jam yaitu $17,25 \%$ dan 24 jam yaitu $15,75 \%$ dengan suhu $60^{\circ} \mathrm{C}$. Hal ini menunjukan bahwa selama pengeringan rumput laut baik yang menggunakan sinar matahari dan cabinet dryer, lebih lama waktu pengeringan maka kadar air dari rumput laut tersebut lebih berkurang.

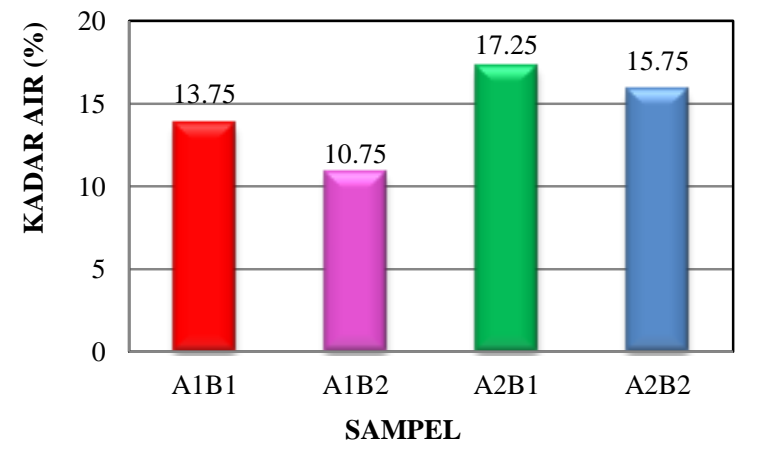

Gambar 2. Histogram analisa kadar air rumput laut (Kappaphycusalvarezii) dengan dua metode pengeringan.

Naiu (2011) dalam Harun (2013) menyatakan bahwa ketebalan bahan berpengaruh terhadap hasil pengeringan. Hal ini terjadi karena semakin tebal bahan, transfer massa dan panas pada bahan akan semakin sulit. Kesulitan ini terjadi karena semakin banyak air terikat pada bahan akan lebih sulit untuk diuapkan dibandingkan dengan air bebas. Hal yang sama juga terjadi pada bahan padatan karena dibanding produk cair, air bebas bahan padatan lebih banyak. Sehingga transfer moisture dan panas akan semakin kecil. Selanjutnya Muller et al, (2006) menyatakan pengeringan dengan alat pengering buatan dianggap lebih menguntungkan karena akan terjadi pengurangan kadar air dalam jumlah besar dalam waktu yang singkat.

Nilai standar kadar air rumput laut kering berdasarkan Standar Nasional Indonesia (SNI 2354-2-2015) adalah maksimal 30\% dan minimal 50\%. Dari hasil penelitian ini menunjukkan bahwa rumput laut yang dikeringkan menggunakan sinar matahari yang tertinggi dengan lama pengeringan selama 40 jam pada pukul 08.00-12.00 yaitu 13,75\%, sedangkan nilai kadar air dari rumput laut yang dikeringkan menggunakan cabinet dryer dengan lama pengeringan 12 jam nilai tertingginya adalah $17,25 \%$. Hasil penelitian ini menunjukkan bahwa produk rumput laut kering masih dalam batas standar yang telah ditentukan oleh SNI. 
Oviantari dan Purwata (2007) dalam Masduqi (2014), menyatakan bahwa proses pengeringan yang tidak merata dan perubahan temperatur secara fluktuatif tersebut mempengaruhi kandungan air. Semakin lama waktu pengeringan yang dilakukan, maka kadar air yang terdapat pada suatu bahan akan semakin rendah.

\section{Hasil Analisa pH}

Hubungan antara rumput laut yang dikeringkan dengan dua metode pengeringan yaitu menggunakan sinar matahari dan cabinet dryer terhadap nilai $\mathrm{pH}$ rumput laut dapat dilihat pada Gambar 3.

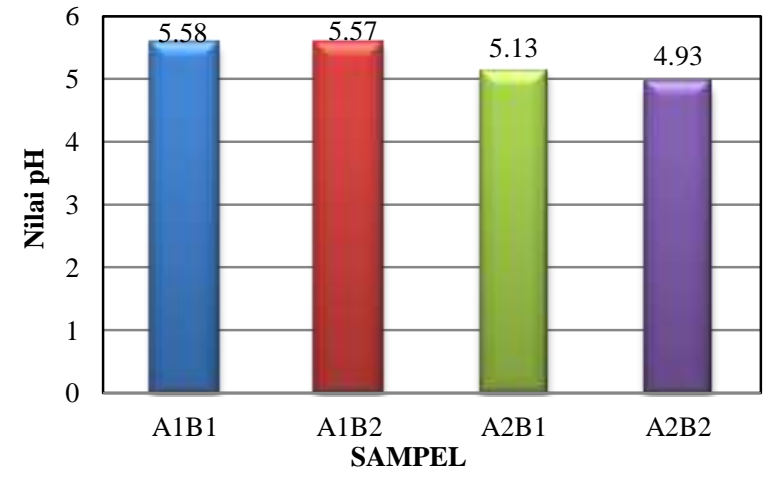

Gambar 3. ilai pH rumput laut (Kappaphycus alvarezii) kering dengan dua metode pengeringan.

Gambar 3 menunjukkan bahwa nilai $\mathrm{pH}$ Rumput Laut yang dikeringkan menggunakan sinar matahari dan cabinet dryer yaitu untuk pengeringan sinar matahari dengan lama pengeringan dari pukul 08.00-12.00 dan dari pukul 12.00-16.00 tidak jauh berbeda. Dari gambar di atas untuk pengeringan menggunakan sinar matahari selama 40 jam pada pukul 08.00-12.00 adalah 5,58 dan untuk pengeringan selama 40 jam pada pukul 12.00-16.00 adalah 5,57. Sedangkan untuk pengeringan cabinet dryer nilai $\mathrm{pH}$ dari rumput laut kering mengalami penurunan sedikit lebih rendah yaitu dengan lama pengeringan 12 jam adalah 5,13 dan untuk pengeringan 24 jam adalah 4,93. dari gambar di atas nilai $\mathrm{pH}$ tertinggi 5,58, pengeringan menggunakan sinar matahari dengan lama pengeringan 40 jam pada pukul 08.00-12.00, sedangkan nilai $\mathrm{pH}$ terendah yaitu 4,93 pengeringan menggunakan cabinet dryer dengan lama pengeringan 24 jam.

Dari hasil penelitian ini dapat dilihat bahwa nilai $\mathrm{pH}$ rumput laut yang dikeringkan menggunakan dua metode pengeringan yaitu bersifat asam.

\section{KESIMPULAN DAN SARAN}

\section{Kesimpulan}

Berdasarkan hasil penelitian Analisa total bakteri (TPC), kadar air dan $\mathrm{pH}$ yang terdapat pada rumput laut (Kappaphycus alvarezii) dengan dua metode pengeringan maka dapat ditarik kesimpulan sebagai berikut:

1. Pengeringan rumput laut dengan menggunakan cabinet dryer merupakan salah satu inovasi untuk pengeringan rumput laut khususnya jenis Kappapphycus alvarezii.

2. Jumlah koloni bakteri pada Rumput Laut (Kappaphycus alvarezii) dengan dua metode pengeringan tidak menunjukkan pengaruh yang nyata terhadap pertumbuhan koloni bakteri.

3. Pengeringan dengan sinar matahari kadar airnya lebih sedikit dibandingkan dengan pengeringan cabinet dryer perbedaan kadar air ini dikarenakan pengeringan menggunakan sinar matahari lebih lama dibandingkan cabinet dryer.

4. Nilai kadar air rumput laut (Kappaphycus alvarezii) yang dikeringkan dengan dua metode berbeda masih dalam batas standar minimum yang ditetapkan oleh SNI (Standar Nasional Inonesia).

5. Nilai pH untuk Rumput Laut (Kappaphycus alvarezii) dengan dua metode pengeringan bersifat asam.

\section{Saran}

Berdasarkan hasil penelitian ini, perlu adanya penelitian lebih lanjut tentang lama pengeringan dengan menggunakan cabinet dryer dan mutu dari rumput laut yang dikeringkan dengan sinar matahari.

\section{DAFTAR PUSTAKA}

AOAC., 1995 Official Methods of Analysis of the Association of Official Analytical. Chemist, Washington.

Dahuri, Rokhmin. 1998. Coastal Zone Management in Indonesia: Issues and Approaches. Journal of Coastal Development 1, No. 2.97-112.

Fardiaz, S. 1993. Analisis Mikrobiologi Pangan. Liberty. Yogyakarta.

Hall CW. 1980. Drying and Storage of Agriculture Crops. Connecticut : The AVi Publishing Company, Inc. Wetsport. 
Hardoko, 2007. Studi Penurunan Glukosa Darah Diabet Dengan Konsumsi Rumput Laut Eucheuma cotonii. Fakultas Perikanan. Universitas Brawijaya Malang. FPIK Institut Pertanian Bogor. 90 hal.

Koentjaraningrat. 1985. Metode-metode Penelitian Masyarakat. Jakarta Gramedia.

Muller, J and Heindl. 2006. Drying Of Medical Plants In R.J. Bogers, L. E. Cracer, and D> Lange (eds), Medical and Aromatic Plant, springer, The Netherland, p.237-252.

Naiu S, L. Mile. Kalaka S.R. 2011. Karakteristik karaginan dari rumput laut $K$. alvarezii pada umur panen yang berbeda. Laporan Hasil Penelitian Pengembangan Program Studi: Hal 1-36.

Oviantari M.V. dan Parwata I.P. 2007. "Optimalisasi Produksi Semi-Refined Carrageenan Dari Rumput Laut Eucheuma cotonii Dengan Variasi Teknik Pengeringan Dan Kadar air Bahan Baku" Jurnal Penelitian dan Pengembangan Sains \& Humaniora, 1 (1): 62-71.
Prajitno, Arief. 2007. Uji Sensitifitas Flavonoid Rumput Laut (Eucheuma cottoni) Sebagai Bioaktif Alami Terhadap Bakteri Vibrio Harveyi. Skripsi. Fakultas Perikanan, Universitas Brawijaya.

Pramono, S. 2006. Penanganan Pasca Panen Dan Pengaruhnya Terhadap Efek Terapi Obat Alami. Prosiding Seminar nasional Tumbuhan Obat Indonesia XXVIII, Bogor, 15-18 Sept.2005. Hal 1-6.

Soegiarto, A.W., S. Ayadja, Sulistidjo dan H. Mubarak. 1987. Rumput Laut (Algae): manfaat, potensi dan usaha budidaya. Lembaga Oseanologi Nasional LIPI. Jakarta: 15-17.

Sugiono 2008, Metode Penelitian Kuantitatif, Kualitatif dan R \& D, Alfabeta, Bandung.

Suptijah, Pipih. 2003. Rumput Laut: Prospek dan Tantangannya. 